\title{
Diversity, distribution and ecology of Davallia in Sumatra (Indonesia) and the nearby small islands
}

\author{
MILDAWATI $^{1,2}$, SOBIR $^{3}$, SULISTIJORINI $^{4}$, TATIK CHIKMAWATI ${ }^{4, \bullet}$ \\ ${ }^{1}$ Plant Biology Graduate Program, Department of Biology, Faculty of Mathematics and Natural Sciences, Institut Pertanian Bogor. Jl. Raya Dramaga, \\ Bogor 16680, West Java, Indonesia \\ ${ }^{2}$ Department of Biology, Faculty of Mathematics and Natural Sciences, Universitas Andalas. Jl. Unand, Limau Manis, Padang 25175, West Sumatra, \\ Indonesia \\ ${ }^{3}$ Department of Agronomy and Horticulture, Faculty of Agriculture, Institut Pertanian Bogor. Jl. Meranti, Kampus IPB Dramaga, Bogor 16680, West \\ Java, Indonesia \\ ${ }^{4}$ Department of Biology, Faculty of Mathematics and Natural Sciences, Institut Pertanian Bogor. Jl. Agatis, Kampus IPB Dramaga, Bogor 16680, West \\ Java, Indonesia. Tel.: +62-251-8622833, `email: tatikch@apps.ipb.ac.id
}

Manuscript received: 14 November 2021. Revision accepted: 7 December 2021.

\begin{abstract}
Mildawati, Sobir, Sulistijorini, Chikmawati T. 2021. Diversity, distribution and ecology of Davallia in Sumatra (Indonesia) and the nearby small islands. Biodiversitas 23: 33-42. Davallia is an epiphytic fern genus that shows high morphological variations in many characters. This genus is widely distributed in the tropics and subtropic areas. The diversity of Davallia has not been explored and recorded in many regions, including in Sumatra Island and its surrounding small islands. Therefore, this research aimed to study the diversity of Davallia species in Sumatra and the nearby small islands based on morphological variation, as well as to investigate their distribution and ecology. Samples were collected from Kerinci Seblat National Park (NP), Bukit Tiga Puluh NP, Siberut NP, Sipora Island, North Pagai Island and South Pagai, Bukit Barisan Grand Forest Park, and Bukit Barisan Selatan NP. In total, 369 specimen sheets (i.e.145 specimens from field explorations and 224 specimens from Herbarium Bogoriense collections) were examined its morphological characters. The results showed that as many as 13 species of Davallia were recorded in Sumatra and the nearby small islands. The species found are D. angustata Wall., D. corniculata T. Moore, D. denticulata (Burm. f.) Kuhn var. denticulata, D. divaricata Blume, D. heterophylla Sm., D. hymenophylloides (B1.) Kuhn, D. parvula Wall., D. pectinata Sm., D. pentaphylla Blume, D. repens Kuhn, D. solida (G.Forst.) Sw. var. solida, D. trichomanoides Blume var. lorranii (Hance) Holttum, D. trichomanoides Blume var. trichomanoides, and D. triphylla Hook. Ten of which were new records for this location. There were 12 spesies found in Sumatra Island except D. parvula Wall. and 11 species found on the small islands around Sumatra except for D. corniculata T. Moore and D. divaricata Blume. Davallia denticulata (Burm. F.) Kuhn var. denticulata and D. solida (G.Forst.) Sw. var. solida had the largest number of specimens found. Almost all species had a random distribution pattern at altitudes of 1000-1500 m above sea level.
\end{abstract}

Keywords: Davallia, distribution, morphology, species diversity

\section{INTRODUCTION}

In western Indonesia, there is an island, a biodiversity hotspot known as Sumatra Island. Sumatra is the third largest island in the Malesia Region, after Borneo and New Guinea (de Kok et al. 2015). Sumatra has a surface area of $434,000 \mathrm{~km}^{2}$ with a length of $1,650 \mathrm{~km}$ from north to south and a width of $350 \mathrm{~km}$ from west to east. This island's most distinctive surface structure is the Bukit Barisan mountain range, stretching from the north end to the south end. The Bukit Barisan forms the ridge of the island of Sumatra and divides the island into two unequal parts. In the east, there is an alluvial lowland (de Kok et al. 2015), while on the west coast of Sumatra Island, there is a range of islands in the geographical area of the Mentawai Islands. The islands included in this area are Siberut, Sipora, North Pagai, and South Pagai Islands. The Mentawai Islands are located approximately between $85-150 \mathrm{~km}$ off the west coast of Sumatra, separated by a deep ocean called the Mentawai Strait (Whitten et al. 2000).

The plant communities found in the Mentawai Islands in primary forests have received ecological protection.
However, most plant species include pteridophytes, under relentless logging and land conversion for decades. This condition prompted the need to study the diversity of pteridophytes in this area.

Pteridophytes (fern group) are the earliest vascular plant that emerged on earth, starting to evolve from the Silurian period, about 400 million years ago. This plant group has the highest number of species after angiosperms, with around 12,000 species globally (Vidyashree 2018). Classification using morphological and molecular characteristics grouped pteridophytes into 4 monophyletic classes, 11 monophyletic orders, 37 families (32 are monophyletic), 312 genera, and 1200 species (Smith et al. 2006). Furthermore, Christenhusz and Chase (2014) classified pteridophytes into 207 genera. Their grouping is different from the PPG I, which are 18 lycophyte and 319 fern genera (PPG I 2016). The higher number of genera in PPG I (2016) was due to new collections and new data, thus encouraging the formation of different taxa (Schuettpelz et al. (2018). Based on anatomical and reproductive characteristics, pteridophytes are a group of vascular plants that produce spores and have a unique 
lineage cycle in the form of free-living gametophyte and sporophyte generations (Haufler et al. 2016). The sporophyte generation is more prominent, with the main structure being rhizomes, stipes, lamina, and frond. This generation is more dominant than the gametophyte generation. Pteridophytes reproduce by spores with various sizes, shapes, colors, and surface patterns of spores. The variations can be used to identify and classify purposes (Wei et al. 2018).

Based on ecological studies, the habitat of pteridophytes varies, including epiphytes, lithophytes, terrestrial, climbing, and hydrophytes (Moran 2004). Nonetheless, pteridophytes have the best habitat in moist and shady forest areas, although several species of pteridophytes can adapt to various habitats (Vidyashree 2018). Temperature, rainfall, topography, availability of solar energy (Hawkins et al. 2003), altitude, soil texture, soil fertility, atmosphere, humidity, evaporation, light intensity, and wind speed determine the growth and geographic distribution pattern of pteridophytes (Hawkins et al. 2003). The ability of spores to disperse over long distances also influenced the distribution patterns of pteridophytes (Patil et al. 2016). Long-distance dispersal causes to be widely distributed on pteridophytes but has high diversity in tropical mountains (Salazar et al. 2015). This article will study about diversity, distribution, and ecology of Davallia, a genus of pteridophytes.

Davallia is an epiphytic fern genus in the Davalliacaea family (Holttum 1998). The Davalliaceae family consists of ten genera based on morphological and molecular studies in different areas (Xing et al. 2013). Davallia has an estimated 65 species (Nooteboom 1998; Smith et al. 2006; Tsutsumi et al. 2016). In Peninsular Malaysia, the Davalliaceae family comprises five genera, including Davallia that consisted of 17 species (Parris and Latiff 1997). In the Malesian Region, Davallia consists of about 23 species, 9 of which are endemic to this region (Nooteboom 1998). Davallia has a creeping rhizome covered by peltate or pseudopeltate scales. Its leaves vary in type and shape. Leaves can be simple to compound and have various venation segments from invisible to visible. Its leaves have various indusium, kidney-shaped or cupshaped, that attach to the edge or along the side at the base of the sorus (Nooteboom 1998).

The advance of science and technology in biosystematics (taxonomical classification of living organisms) cannot be separated from the diversity of morphology in nature. Morphological-based classification of pteridophytes has been debated, but this is still instrumental in developing recent classification (Schneider 2013). Therefore, the differences between species in the genus Davallia still need to be carried out more in-depth studies based on morphological evidence of each species. This study needs botanical exploration in areas not yet been explored, such as Sumatra Island and its surrounding small islands. The analysis of vertical distribution based on comprehensive ecological data and the ability to grow at different altitudes of Davallia species in the Malesian region is also not available. This study aimed to complete information on the diversity and distribution of Davallia species in Sumatra and the nearby small islands based on morphological features and ecological data and investigate the vertical and horizontal distribution of the species.

\section{MATERIALS AND METHODS}

\section{Plant materials}

Samples consisted of specimens collected directly through botanical exploration in the field and herbarium collections at the Herbarium Bogoriense (BO), Research Center for Biology, Indonesian Institute of Sciences (LIPI), Cibinong, West Java. The results of exploration were stored in ANDA Herbarium (Andalas University). Specimen observation was carried out on 369 specimens (i.e., 145 specimens from the exploration and 224 specimens from BO collections) with sources of collection from various regions in Sumatra Region and nearby small islands. Sample locations were determined based on altitude and soil topography. The first location was in Kerinci Seblat National Park with an altitude from 5001400 masl (consisted of three areas: National Park Management Section I in Painan Pesisir Selatan, West Sumatra, Section III in Jambi Province, and Section IV in Sangir, Solok Selatan, West Sumatra). The second location was Bukit Tiga Puluh NP in Talang Lakat, Indragiri Hulu, Riau Province at an altitude of 30-500 masl. The third was Siberut NP, Sipora Island, North Pagai Island and South Pagai Island, which altogether these islands belong to Mentawai Island, West Sumatra Province with an altitude of 0-200 masl. The fourth location was Bukit Barisan Grand Forest Park, North Sumatra Provinces with an altitude $800-1000 \mathrm{~m}$ asl, and the fifth was Bukit Barisan Selatan NP in South Sumatra Province, Region I Semaka at an altitude of 500-600 masl.

Field data recorded included location site, coordinates, altitude from sea level and the type of host. Environmental data such as rainfall, wind speed, humidity, temperature were obtained from Meteorology, Climatology and Geography (BMKG) of West Sumatra, Indonesia. Morphological data were obtained from observations of 25 characteristics of rhizomes, stems and leaves (Table 1). The terminology used in this observation is based on Hickey and King (2000). The identification of the Davallia species was determined based on morphological characteristics which include variations in the shape of rhizomes, stypes, leaves and sorus. Species that were difficult to identify in the field were collected and then made a specimen herbarium. Specimens were identified using several reference books, namely Copeland (1958); Holttum (1955); Kato (1985); Nooteboom (1992, 1994, 1998); Shieh et al. (1994) and Xing et al. (2013). Scientific name validation was carried out by referring to the page http://www.plantsoftheworldonline.org/. Morphological characteristics and traits that differentiate species in the genus Davallia are presented in Table 1. 
Table 1. Morphological characteristics to differentiate Davallia species and the codes used for classification

\begin{tabular}{|c|c|c|c|c|c|}
\hline \multirow{2}{*}{$\begin{array}{l}\text { Characters } \\
\text { Rhizome }\end{array}$} & \multicolumn{5}{|c|}{ Character states and codes } \\
\hline & \multirow{2}{*}{ 0. Small (0-5) } & \multirow[b]{2}{*}{ 1. Medium (5-10) } & \multirow[b]{2}{*}{ 2. Large $>10$} & & \\
\hline Diameter (mm) & & & & & \\
\hline White waxy under the scale & 0. Absent & 1. Present & & & \\
\hline Pale border & 0 . Absent & 1. Present & & & \\
\hline Scale & 0. Pseudopeltate & 1. Peltate & & & \\
\hline Curling backward & 0 . Absent & 1. Present & & & \\
\hline Scale apex & 0 . Flatten & 1. Peltate & 2. Filiform & & \\
\hline \multicolumn{6}{|l|}{ Stipe } \\
\hline Diameter (mm) & 0. Small (0-5) & 1. Medium (5-10) & 2. Large $>10$ & & \\
\hline Adaxial grooved & 0 . Absent & 1. Present & & & \\
\hline Color & 0. Green & 1. Yellow & & & \\
\hline \multicolumn{6}{|l|}{ Lamina } \\
\hline Formation & 0. Lanceolate & 1. Deltoid & 2. Multifid & 3. Pinnatisect & \\
\hline Number & 0. Unifolium & 1. Multifolium & 2. Imparripinnatus & & \\
\hline Lamina symmetry & 0 . Asymmetrical & 1. Symmetrical & & & \\
\hline Dimorphism & 0 . Absent & 1. Present & & & \\
\hline Pinna & 0. Apinnatus & 1. Pinnatus & 2. Bipinnatus & 3. Tripinnatus & \\
\hline Apex & 0. Attenuate & 1. Acuminate & 2. Dichotome & 3. Obtuse & 4. Acutus \\
\hline Basis & 0. Obtuse & 1. Cuneate & 2. Rounded & 3. Multifid & 4. Perfuliate \\
\hline Margin & 0. Entire & 1. Crenulate & 2. Dentate & 3. Serrate & \\
\hline Lobation & 0 . Unlobed & 1. Multy Lobed & 2. Pinnately lobed & & \\
\hline False veins & 0. Absent & 1. Present & & & \\
\hline Venation & 0. Forked & 1. Forked and Free & & & \\
\hline Pinna size & 0. Small $(0-5)$ & 1. Medium (5-10) & 2. Large $>10$ & & \\
\hline Spacing of Margin Lamina & 0. Irregular & 1. Regular & & & \\
\hline Ultimate segment & 0. Absent & 1. Present & & & \\
\hline \multicolumn{6}{|l|}{ Sori } \\
\hline Position & 0. Marginal & 1. Submarginal & & & \\
\hline Indusium & 0. Oblong & 1. Rhomboid & 2. Semicircular & 3. Reniform & \\
\hline
\end{tabular}

\section{Data analysis and presentation}

Morphological data were analyzed qualitatively. The results of the analysis were presented in diagrams and tables. The data from the morphological observations were arranged in the form of a data matrix. The data matrix was used to determine a similarity between species using a simple matching similarity index, and then used the index for cluster analysis using the UPGMA (Unweighted Pair Group Method with Arithmetic Mean) method. Cluster analysis was performed using NTSYS (Numerical Taxonomy and Multivariate System) version 2.02 (Rohlf 1998).

\section{RESULTS AND DISCUSSION}

\section{Identification and clustering of Davallia in Sumatra and the nearby small islands}

Based on the observations on 369 specimens of Davallia collected from Sumatra and the nearby small islands, there were thirteen species and two varieties in these locations (Table 1, Figure 1). The species found were $D$. angustata Wall., D. corniculata T. Moore, D. denticulata (Burm. f.) Kuhn var. denticulata, D. divaricata Blume, D. heterophylla Sm., D. hymenophylloides (Bl.) Kuhn, D. parvula Wall., D. pectinata Sm., D. pentaphylla Blume, D. repens Kuhn, D. solida (G. Forst.) Sw. var. solida, D. trichomanoides Blume var. lorranii (Hance) Holttum, D. trichomanoides Blume var. trichomanoides, and D. triphylla Hook. Davallia species are easily distinguished by four characters: frond shape and size, leaf shape, and pinna arrangement. Besides, Davallia species also vary in many characters, such as the rhizome size, shape of the scale and base scales on the rhizome, stipe shape and size, venation type, sorus size, and location on the leaves. We found some new morphological characteristics that were not reported previously: leaf apex and base, venation type, the arrangement of the pinna, pinna size, and the position of the sorus.

Based on the field data, only two species were found on Siberut Island and Sipora Island, and three species from North Pagai Island, Mentawai Islands, with the new record of $D$. heterophylla $\mathrm{Sm}$. on this Island (Table 1). The number of species found is much lesser than the Davallia species found in Siberut NP (Mildawati et al. 2020). The dominant species found were D. denticulata (Burm. F.) Kuhn var. denticulata and D. solida (G. Forst.) Sw. var. solida. Both species are very adaptive and widely distributed in Sumatra and the surrounding small islands. However, these two species found in North Pagai and South Pagai have different frond and sorus features than the same species found in other locations.

Ten Davallia species (145 specimens) were found in the field including $D$. corniculata T.Moore, $D$. denticulata 
(Burm. f.) Kuhn var. denticulata, D. divaricata Blume, D. heterophylla Sm., D. hymenophylloides (B1.) Kuhn, D. pectinata Sm., D. pentaphylla Blume, D. repens Kuhn, D. solida (G.Forst.) Sw. var. solida, dan D. trichomanoides Blume var. trichomanoides. But, three species were not found during the field exploration due to the limited suitable habitat for their growth. Based on herbarium specimen data, D. angustata Wall. is species that has a habitat on river banks and is generally found in small islands in the eastern part of Sumatra such as Bangka Island and Riau Islands (Kepri) from an altitude of 0-1300 masl. Davallia parvula Wall. originated from Bangka Island and Riau Islands is estimated to have a suitable habitat on small islands in eastern Indonesia. Davallia trichomanoides Blume var. lorranii (Hance) Holttum was found in a collection from the northern part of the island of Sumatra which is thought to be more favorable to environmental factors for this species' habitat to grow and D. triphylla Hook. was found around big rivers areas in Sumatra (Nooteboom 1998).

Species considered as new records for the island of Sumatra include $D$. corniculata T. Moore, D. denticulata (Burm. f.) Kuhn var. denticulata, D. divaricata Blume, D. hymenophylloides (Bl.) Kuhn, D. pectinata Sm., D. pentaphylla Blume, D. repens Kuhn, D. solida (G. Forst.) Sw. var. solida, dan D. trichomanoides Blume var. trichomanoides found in TN Kerinci Seblat NP, and D. denticulata (Burm. f.) Kuhn var. denticulata, and D. solida (G. Forst.) Sw. var. solida found in Bukit Tiga Puluh NP and Bukit Barisan Selatan NP.
Identification keys of Davallia from Sumatra and the nearby small islands:

1. a. Lamina formation deltoid, pinna tripinnantus or bipinnatus tripingantus or biping

b. Lamina formation lanceolate, multifid or pinnatisect ..... 5

2. a. Rhizome scale pseudopeltate ………………................ 3

b. Rhizome scale peltate ............................... 4

3. a. Apex scale peltate ....... D. hymenophylloides (B1.) Kuhn b. Apex scale filiform

.... D. trichomanoides Blume var. lorranii (Hance) Holttum

4. a. Lamina dimorfisme present ................. D. repens Kuhn

b. Lamina dimorfisme absent ................................. 6

5. a. Lamina base rounded ..................... D. heterophylla Sm.

b. Lamina base not rounded................................................ 10

6. a. False vein in lamina present............................................. 7

b. False vein in lamina absent .......................................... 9

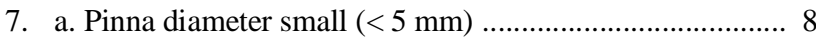

b. Pinna diameter large $(>10 \mathrm{~mm})$ D. denticulata (Burm. f.) Kuhn var. denticulata

8. a. White waxy under scale ........... D. corniculata T.Moore b. No white waxy under scale

D. trichomanoides Blume var trichomanoides

9. a. Pale border in rhizome scale present

....................... D. solida (G.Forst.) Sw. var. solida

b. Pale border in rhizome scale absent

D. divaricata Blume

10. a. Lamina imparripinnatus ........................ D. parvula Wall. b. Lamina unifoliate

11. a. Margin lamina serrate....................... pentaphylla Blume b. Margin lamina entire or crenulate ......

12. a. Indusium oblong ................................... triphylla Hook. b. Indusium semicircular ................................13

13. a. Pinnatus ………………………......... D. pectinata $\mathrm{Sm}$. b. Apinnatus .......................................... D. angustata Wall.

Table 2. List of Davallia species with geographical distribution in Sumatra and the nearby small islands

\begin{tabular}{|c|c|c|c|c|c|c|}
\hline Species & Herbarium collections & Field collection & 1 & 2 & 3 & 4 \\
\hline D. angustata Wall. & $\sqrt{ }$ & - & - & - & - & - \\
\hline D. corniculata T.Moore & $\sqrt{ }$ & $\sqrt{ }$ & - & - & - & - \\
\hline D. denticulata (Burm. f.) Kuhn var. denticulata ${ }^{2,3,4}$ & $\sqrt{ }$ & $\sqrt{ }$ & - & $\sqrt{ }$ & $\sqrt{ }$ & $\sqrt{ }$ \\
\hline D. divaricata Blume & $\sqrt{ }$ & $\sqrt{ }$ & - & - & - & - \\
\hline D. heterophylla $\mathrm{Sm}^{3}$ & $\sqrt{ }$ & $\sqrt{ }$ & - & - & $\sqrt{ }$ & - \\
\hline D. hymenophylloides (Bl.) Kuhn & $\sqrt{ }$ & $\sqrt{ }$ & - & - & - & - \\
\hline D. parvula Wall. & $\sqrt{ }$ & - & - & - & - & - \\
\hline D. pectinata $\mathrm{Sm}$. & $\sqrt{ }$ & $\sqrt{ }$ & - & - & - & - \\
\hline D. pentaphylla Blume & $\sqrt{ }$ & $\sqrt{ }$ & - & - & - & - \\
\hline D. repens Kuhn ${ }^{1}$ & $\sqrt{ }$ & $\sqrt{ }$ & $\sqrt{ }$ & - & - & - \\
\hline D. solida (G.Forst.) Sw. var. solida $a^{1,2,3,4}$ & $\sqrt{ }$ & $\sqrt{ }$ & $\sqrt{ }$ & $\sqrt{ }$ & $\sqrt{ }$ & $\sqrt{ }$ \\
\hline a. D. trichomanoides Blume var. lorranii (Hance) Holttum & $\sqrt{ }$ & - & - & - & - & - \\
\hline b. D. trichomanoides Blume var. trichomanoides & $\sqrt{ }$ & $\sqrt{ }$ & - & - & - & - \\
\hline D. triphylla Hook. & $\sqrt{ }$ & - & - & - & - & - \\
\hline
\end{tabular}

Note: Exploration location of Davallia: 1. Siberut Island; 2. Sipora Island; 3. North Pagai Island; 4. South Pagai Island. V: Species found during exploration; -: species not found during exploration 


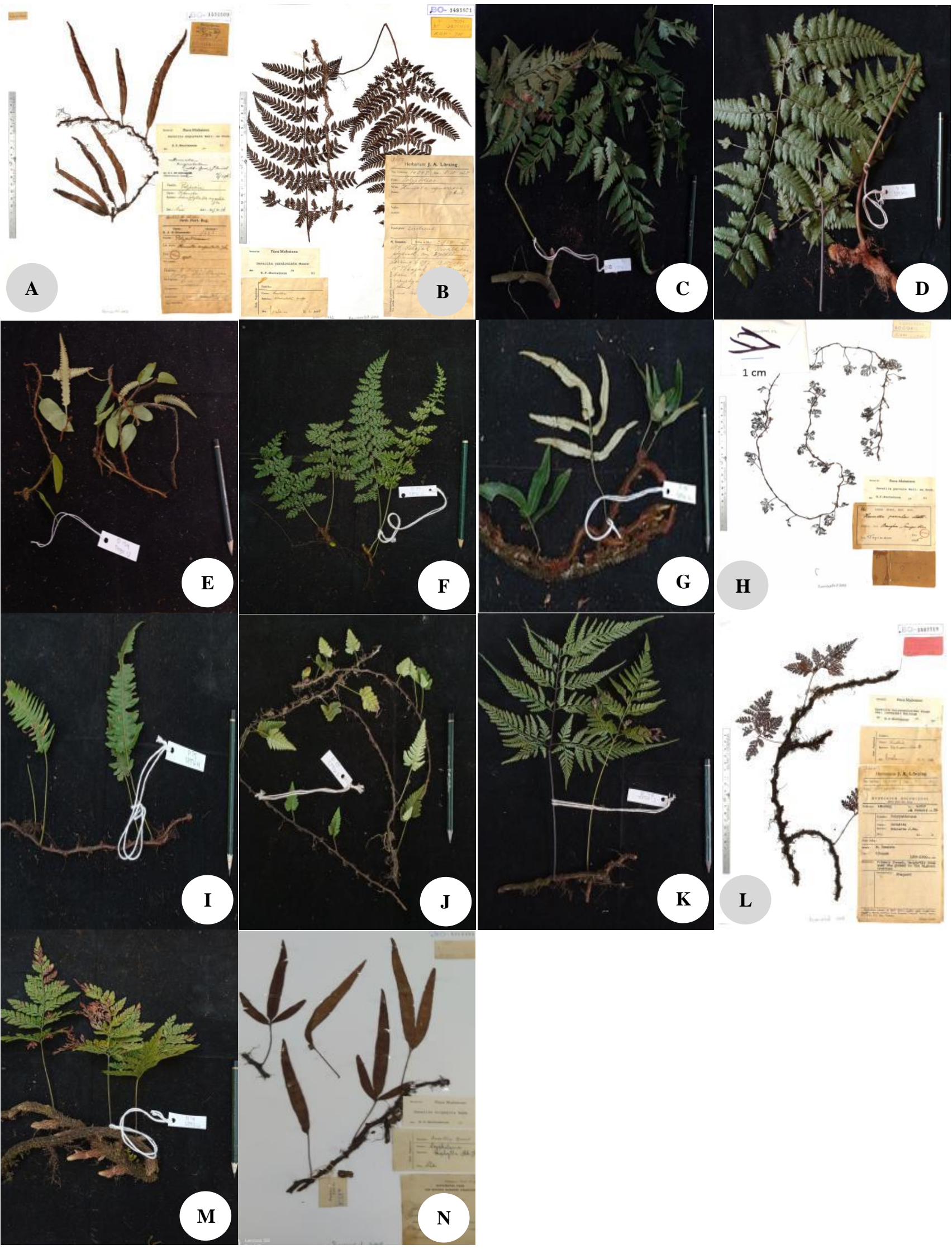

Figure 1. Morphology of Davallia species in Sumatra and the nearby small islands: A. D. angustata Wall; B. D. corniculata T.Moore; C. D. denticulata (Burm. f.) Kuhn var. denticulata; D. D. divaricate Blume; E. D. heterophylla Sm.; F. D. hymenophylloides (Bl.) Kuhn; G. D. parvula Wall.; H. D. pectinata Sm.; I. D. pentaphylla Blume; J. D .repens Kuhn; K. D. solida (G.Forst.) Sw. var. solida; L. D. trichomanoides Blume var. lorranii (Hance) Holttum; M. D. trichomanoides Blume var. trichomanoides; N. D. triphylla Hook 


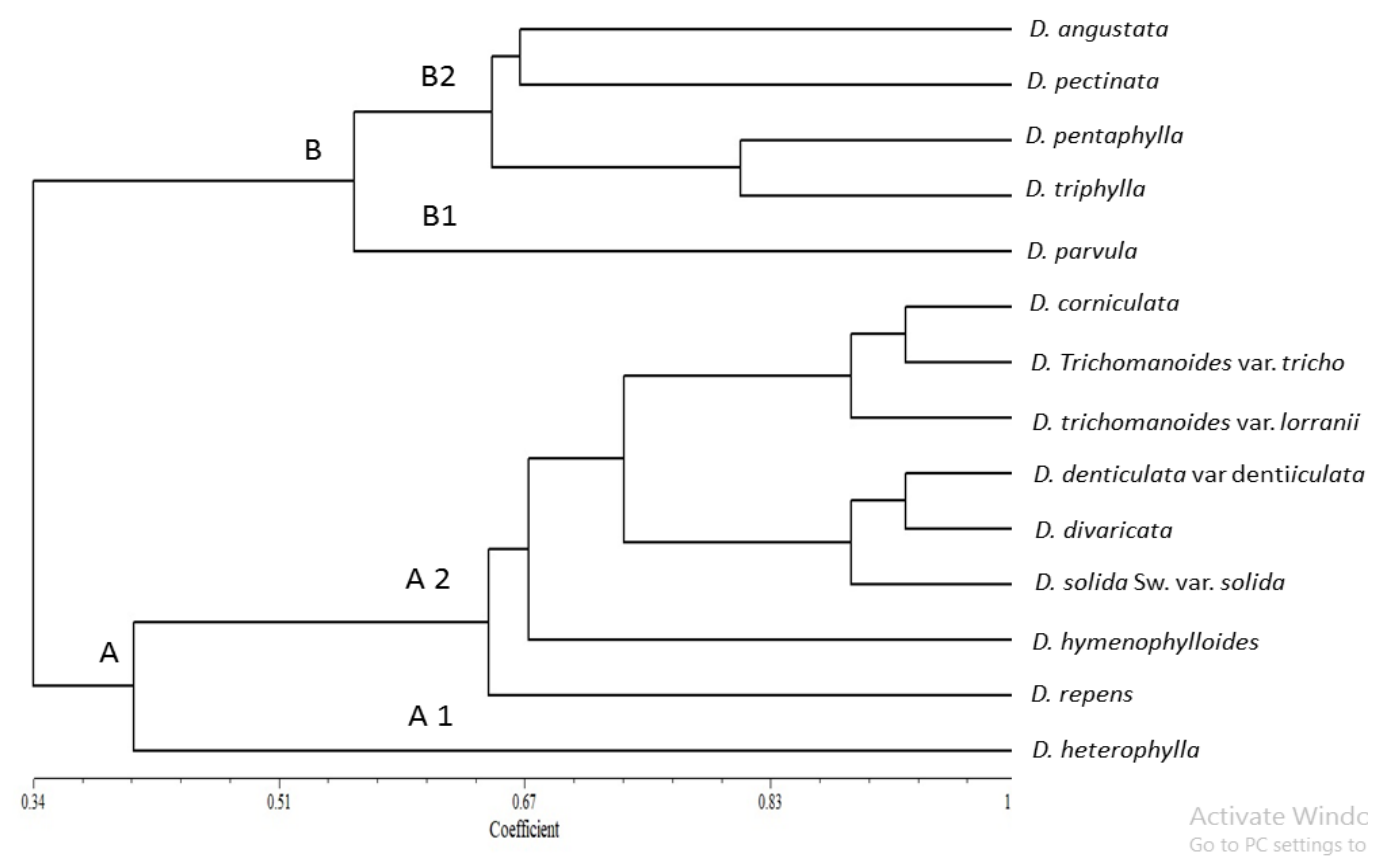

Figure 2. Dendrogram of Davallia in Sumatra and the nearby small islands based on morphological characteristics inferred using UPGMA method.

The exploration in the Mentawai Islands as representatives of small islands around Sumatra found a new record of Davallia species, namely D. denticulata (Burm. f.) Kuhn var. denticulata, D. solida (G.Forst.) Sw. var. solida and D. heterophylla $\mathrm{Sm}$. from North Pagai Island and D. denticulata (Burm. f.) Kuhn var. denticulata, and D. solida (G.Forst.) Sw. var. solida from Sipora Island and South Pagai Island. This result adds information about Davallia species' existence from small islands except for Siberut NP in Siberut Island (Mildawati et al. 2020).

Similarities between the Davallia species are presented in a dendrogram (Figure 2). Phenetic analysis of 13 Davallia species using 25 morphological features resulted in two large clades (A and B) with similarity coefficient of 0.34 (Figure 2). Clade A has two smaller clades with a similarity coefficient of 0.4 , namely A1 and A2. Clade A1 consists of $D$. heterophylla Sm., while Clade A2 consists of D. corniculata T. Moore, D. trichomanoides Blume var. lorranii (Hance) Holttum, D. trichomanoides Blume var. trichomanoides, D. denticulata (Burm. f.) Kuhn var. denticulata, D. divaricata Blume, D. solida (G. Forst.) Sw. var. solida, D. hymenophylloides (B1.) Kuhn and D. repens Kuhn. Davallia species in Clade A2 has similarities in several characteristics, namely deltoid frond, compound leaves, tripinnatus, acuminate apex, cuneate base, dentate leaf margins, reticulate venations, irregular tooth spacing of the lamina margin, and sorus position on the marginal of leaves.

Clade B is composed of two main groups, B1 and B2, with a similarity coefficient of 0.56 . Clade B1 consists of only one species, D. parvula Wall., while Clade B2 contains D. angustata Wall., D. pectinata Sm., D. pentaphylla Blume, and D. triphylla Hook. Davallia species in clade B share five characters: the circumference of the small rhizome less than $5 \mathrm{~mm}$, peltate scales, unifoliate leaves, no false veins, and free venation.

The clustering result is consistent with Maideen et al. (2009) based on a combination of morphological data and phylogenetic trees of molecular studies which grouped $D$. corniculata T. Moore, D. trichomanoides Blume var. lorranii (Hance) Holttum, D. trichomanoides Blume var. trichomanoides into the same clade. Likewise, $D$. denticulata (Burm. f.) Kuhn var. denticulata, D. divaricata Blume and D. solida (G. Forst.) Sw. var. solida was being in the same clade.

\section{The distribution of Davallia in Sumatra and the nearby small islands}

Based on observations of herbarium specimens and the results of field exploration (Figure 3), the number of species found on the mainland of Sumatra is more diverse when compared to small islands in the vicinity. Of the eleven new records, ten species were found in the mainland of Sumatra and the neighboring small islands. Two species, $D$. corniculata T. Moore and $D$. divaricata Blume, were only found in the mainland of Sumatra. One species, $D$. parvula Wall, was not found in the mainland of Sumatra but only found in the Bangka and Lingga islands, consisting of only three specimens, two specimens from the Mount Rebo and Selan River, Bangka Island, and one specimen from Selayar Island, Lingga District, Riau Islands.

In the context of small islands around Sumatra, four species of Davallia were found in the Mentawai Islands the island in the western part of Sumatra - namely $D$. denticulata (Burm. f.) Kuhn var. denticulata, D. 
heterophylla Sm., D. repens Kuhn, D. solida (G. Forst.) Sw. var. solida. Furthermore, 6 species of Davallia were found in Enggano Island, including D. denticulata (Burm. f.) Kuhn var. denticulata, D. heterophylla Sm., D. pectinata Sm., D. repens Kuhn, D. solida (G. Forst.) Sw. var. solida and $D$. trichomanoides Blume var. trichomanoides. Small islands located in the eastern part of Sumatra Island include the Riau Islands which consists of several islands. The first, Lingga Island, three species were found, i.e. D. angustata Wall. collected from Mount Daik, Sepincan and Lesung, D. heterophylla Sm. only from Lingga Island, and D. parvula Wall. from Selayar Island, Lingga District. The second, Bintan Islands, where $D$. denticulata (Burm. f.) Kuhn var. denticulata and D. repens Kuhn were found. Third, Karimun Islands, there were three species found, namely D. pectinata $\mathrm{Sm}$., D. pentaphylla Blume, and D. trichomanoides Blume var. Trichomanoides. The fourth, Natuna Island and Anambas Island, only one species found, i.e. D. repens Kuhn. Furthermore, four species, namely D. angustata Wall., D. denticulata (Burm. F.) Kuhn var. denticulata, D. parvula Wall., and D. repens Kuhn. were recorded in Bangka and Belitung islands.

The above results suggest that the mainland of Sumatra has a greater number of species diversity than the nearby small islands, which is understandable since Sumatra mainland has a greater extent of area than the nearby islands (Myers et al. 2000). Sumatra supports some of the largest expanses of tropical rainforests in Southeast Asia, providing some of the species richest habitats on earth with 9,000-10,000 species of plant (MacKinnon et al. 1996; Whitten et al. 2000). This region was formed as a result of a major upthrust that occurred 20 million years ago and was accompanied by considerable faulting and violent volcanic activities which shaped the present form of Sumatra (Whitten et al. 2000). Limited information on the diversity of Davallia species from Sumatra Island and nearby small islands is a challenge to carry out more indepth exploration and research.

Based on the distribution of Davallia, Nooteboom (1998) informed that there were nine species endemic to the Malesian region, including D. brassii (Copel.) Noot., $D$. brevipes Copel., D. falcinella (J. Sm.) C. Presl, dan D. rouffaeriensis Noot., D. sessilifolia Blume, $D$. sessilifoliodes M. Kato, D. triphylla Hook. D. undulata (Aldrew.) Noot. and D. wagneriana Copel., all of them from the eastern part of the Malesian region. This result is consistent with our exploration results which shows that the nine species were not found during our exploration. One species of interest here is D. triphylla Hook, which is an endemic species to the eastern part of the Malesian region. This species has similarities to $D$. pentaphylla Blume in many characters such as rhizomes, scales on the rhizomes, leaf shape, and sorus shape, but they are different in leaf number.

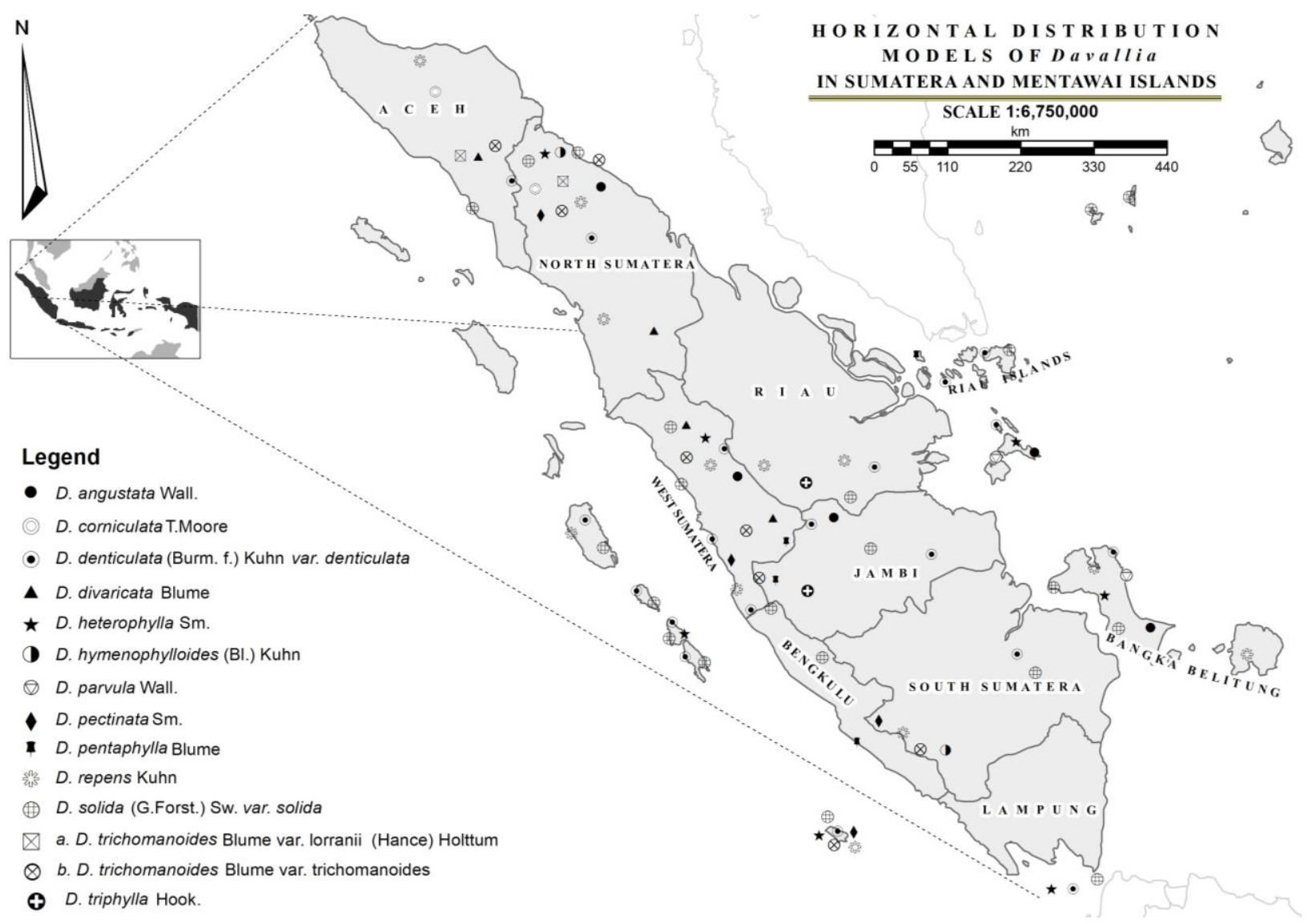

Figure 3. The geographical distribution of Davallia in Sumatra and the nearby small islands 


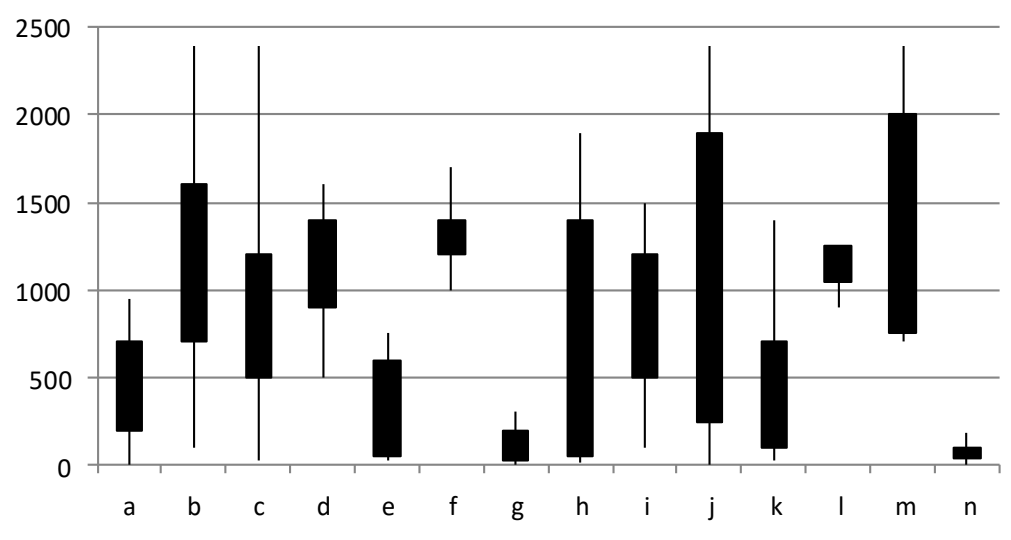

Figure 4. Vertical distribution of Davallia in Sumatra and the nearby small islands. A. D. angustata Wall.; B. D. corniculata T. Moore; C. D. denticulata (Burm. f.) Kuhn var. denticulate; D. D. divaricata Blume; E. D. heterophylla Sm.; F. D. hymenophylloides (Bl.) Kuhn; G. D. parvula Wall.; H. D. pectinata Sm.; I. D. pentaphylla Blume; J. D. repens Kuhn; K. D. solida (G. Forst.) Sw. var. solida; L. D. trichomanoides Blume var. lorranii (Hance) Holttum; M. D. trichomanoides Blume var. trichomanoides; N. D. triphylla Hook

\section{The ecology of Davallia in Sumatra and the nearby small islands}

The analysis of ecological data from specimens collected in the field and observations of herbarium specimens stored in BO showed that Davallia species in Sumatra and the nearby small islands are generally cosmopolitan species (Figure 3). Based on exploration in the field, several species, i.e. D. corniculata T.Moore, D. divaricata, D. pentaphylla, D. hymenophylloides (B1.) Kuhn, D. pectinata and D. trichomanoides var trichomanoides grew in specific habitats. These species were found in the primary forest overgrown by pine trees, such as in the Lake Bontak area in Kerinci Seblat NP and the forest of Bukit Barisan Forest Park in Medan, North Sumatra at an altitude of 1300 masl. The area has an average temperature ranging from $24.6-29.4{ }^{\circ} \mathrm{C}$, average humidity between $68-96 \%$, average rainfall between 0.3 $130 \mathrm{~mm}$, sun exposure between 0.2-9.5 hours long, and average wind speed of $0-3 \mathrm{~m} / \mathrm{s}$.

Based on the altitude data where the host grows, the species in this genus can survive at various altitudes with different hosts ranging from the coast to an altitude of 1,400 masl (Figure 4). This genus grew on several hosts, including durian (Durio zibethinus Murray), oil palm (Elaeis guineensis Jacq.), and pine (Pinus merkusii Jungh. \& Vriese ex Vriese). Most Davallia has a habit of epiphytes and lithophytes. Some Davallia plants were also found growing as a creeping terrestrial, such as $D$. denticulata (Burm. F.) Kuhn var. denticulata grows near its primary habitat on damp rocks by the river.

The rich diversity of Davallia was found at an altitude of 1000-1500 masl. The number and diversity of Davallia species decreased in the lowlands. This result is in line with the result of exploration in the Bukit Tiga Puluh NP as a lowland area with an altitude of 200 masl, where only two species were found, i.e. D. denticulata (Burm. F.) Kuhn var. denticulata and D. solida (G. Forst.) Sw. var. solida. But this condition is in contrast to western Sumatra. Davallia found in the field were grouped into seven categories based on their elevation area, namely 1) Lowlands, altitude of $0-150 \mathrm{~m}$ asl; 2) Low elevation hill, altitude of $150-500 \mathrm{~m}$ asl; 3) Medium elevation hill, altitude of 500-900 masl; 4) Submontane, altitude of 9001,400 m asl; 5) Lower montane, altitude of 1,400-1,900 m asl; 6) Montane, altitude of 1900-2500 $\mathrm{m}$ asl and; 7) Tropical upper montane and subalpine, altitude > 2500 mas 1 (Lawnonier 1977).

The results of this study were in line with the previous research that reported the number of epiphytic plants found in moist forests was relatively higher than those found in dry areas (Rajbhandary 2016). This result is also consistent with data that shows the low diversity of species found in eastern Sumatra such as Bukit Tiga Puluh NP, where rainfall does not show a clear correlation with temperature and altitude. Still, the temperature shows an opposite correlation with altitude. Rainfall and ambient temperature are parameters that influence species distribution because no single variable can explain the distribution of plants (Mc Cain and Grytnes 2010).

The vertical distribution of some Davallia species tends to live at various altitudes ranging from the coastal area at an altitude of $0-150 \mathrm{~m}$ asl to an altitude> $2000 \mathrm{~m}$ asl (Figure 4). However, based on specimen herbarium observation, there were no data on Davallia species found at an altitude $>2400 \mathrm{~m}$ asl. Species found in coastal areas at an altitude of 0-500 m asl included D. angustata Wall., D. heterophylla Sm., D. parvula Wall., D. solida (G.Forst.) Sw. var. solida, dan D. triphylla Hook. Species found at an altitude of 500-900 m asl included D. denticulata (Burm. f.) Kuhn var. denticulata. The species that dominated the highlands at an altitude of 900-1,400 $\mathrm{m}$ asl were $D$. corniculata T.Moore, D. divaricata Blume, D. hymenophylloides (B1.) Kuhn, D. trichomanoides Blume var. lorranii (Hance) Holttum, D. trichomanoides Blume var. trichomanoides. In this area, species were found to be more diverse than in other areas, because the diversity of Davallia shows a significant correlation with altitude and temperature. Most of the pteridophytes species are found in 
humid places above $1500 \mathrm{~m}$ asl (Nepali et al. 2020). Low mountains located at an altitude of 1,400-1,900 $\mathrm{m}$ asl have a limited distribution of species. The species of Davallia that can be found in this area included D. pectinata $\mathrm{Sm}$. and $D$. repens Kuhn. The diversity of plant species found is associated with their vertical distribution, indicating that species distribution is correlated with the number of specimens found. The trend obtained in this study is that the more the number of specimens found, the wider the distribution of the species. On the other hand, the smaller the number of specimens found, the narrower the distribution. Thus, the diversity of pteridophytes species is higher based on the horizontal distribution compared to the vertical distribution (Xiang et al. 2017).

In conclusion, a total of 13 species with 4 varieties were found in Sumatra Island and the nearby small islands, consisting of D. angustata Wall., D. corniculata T.Moore, D. denticulata (Burm. f.) Kuhn var. denticulata, D. divaricata Blume, D. heterophylla Sm., D. hymenophylloides (B1.) Kuhn, D. parvula Wall., D. pectinata Sm., D. pentaphylla Blume, D. repens Kuhn, D. solida (G.Forst.) Sw. var. solida, D. trichomanoides Blume var. lorranii (Hance) Holttum, D. trichomanoides Blume var. trichomanoides, dan D. triphylla Hook. Two dominant species were $D$. denticulata (Burm. f.) Kuhn var. denticulata and D. solida (G.Forst.) Sw. var. solida. All species found are new information for this area. Among Davallia species, it can be distinguished based on four main characteristics, namely the shape and size of the frond, leaf shape, and pinna arrangement. In addition, five new distinguishing characteristics that had not been previously reported were found, namely the shape of the leaf tip and base, the shape of the leaf veins, the size of the pinna and the position of the sorus. Davallia had a cosmopolitan distribution pattern and is generally found at an altitude of 1000-1500 m asl. Davallia species found in Sumatra were more diverse than the surrounding small islands so that there is a positive correlation between the diversity of species in an island and the size of the island. Within Sumatra Island, the distribution pattern of Davallia was more diverse in the Bukit Barisan range in the western part of Sumatra Island compared to the lowland area in eastern Sumatra. The diversity of Davallia species was also largely determined by the type of habitat. In habitats with high humidity above $70 \%$, this genus was more diverse than those with low humidity. Certain species such as $D$. pectinata Sm., D. repens Kuhn. and D. trichomanoides Blume var. trichomanoides was only found in areas that have high humidity.

\section{ACKNOWLEDGEMENTS}

The authors would like to acknowledge the research grant from the Ministry of Research and Technology/ National Research and Innovation Agency (BRIN) with IPB University through the research Penelitian Disertasi Doktor 2020 No: 1/E1/KP.PTNBH/2020 (March 18th 2020) and Penelitian Disertasi Doktor No: 1/E1/KP.PTNBH/2021 (March, 8th 2021).

\section{REFERENCES}

Christenhusz MJM, Chase MW. 2014. Trends and concepts in fern classification. Ann Bot 113 (4): 571-594. DOI: 10.1093/aob/mct299.

Copeland EB. 1958. Fern Flora of The Philippines, Vol 1. Bureau of Printing, Manila.

de Kok RPJ, Briggs M, Pirnanda D, Girmansyah D. 2015. Identifying targets for plant conservation in Harapan rainforest, Sumatra. Trop Conserv Sci 8 (1): 28-32.

Haufler CH, Pryer KM, Schuettpelz E, Sessa EB, Farrar DR, Moran R, Schneller JJ, Watkins Jr JE, Windham MD. 2016. Sex and the single gametophyte: Revising the homosporous vascular plant life cycle in light of contemporary research. BioScience 66 (11): 928-937. DOI: 10.1093/biosci/biw108.

Hawkins BA, Field R, Cornell HV, Currie DJ, Guégan JF, Kaufman DM, Kerr JT, Mittelbach GG, Oberfoff T, O’Brien EM, Porter EE, Turner JRG. 2003. Energy, water, and broad-scale geographic patterns of species richness. Ecology 84 (12): 3105-3117. DOI: 10.1890/038006.

Hickey M, King C. 2000. The Cambridge Illustrated Glossary of Botanical Term. Cambridge University Press, United Kingdom.

Holttum RE. 1955. A Revised Flora of Malaya: An Illustrated Systematic Account of The Malayan Flora, Including Commonly Cultivated Plants, Vol. 2, Ferns of Malaya, ed 2. Government Printing Office, Singapore.

Holttum RE. 1966. A revised Flora of Malaya, Vol II Ferns of Malaya, Second edition. Government Printing Office, Singapure.

Kato M. 1985. A systematic study of the genera of the fern family Davalliaceae. Journal of the Faculty of Science, University of Tokyo 13 (5): 553-573.

Lawnonier Y. 1977. The Vegetation and Physiography of Sumatra. Kluwer Academic Publishers, London.

MacKinnon K, Gusti H, Hakimah H, Arthur M. 1996. The Ecology of Kalimantan: Indonesian Borneo. The Ecology of Indonesia Series III. Periplus Editions.

Maideen H, Milne RI, Gibby M. 2009. Davalliaceae in Peninsular Malaysia, a preliminary study based on trnL-F region. J Plant Taxon Plant Geogr 54 (1-3): 203-206. DOI: 10.3767/000651909X476166.

Mc Cain CM, Grytnes JA. 2010. Elevational Gradients in Species Richness, Encyclopedia of Life Sciences. John Wiley \& Sons, Ltd. USA. DOI: 10.1002/9780470015902.a0022548.

Mildawati M, Sobir S, Sulistijorini S, Chikmawati T. 2020. The Diversity of Pteridophytes In Siberut National Park, Mentawai Islands, West Sumatra, Indonesia. Biodiversitas 21 (7): 3200-3208. DOI: 10.13057/biodiv/d210742.

Moran RC, 2004. A Natural History of Ferns. Timber Press, Portland, US.

Myers N, Mittermeier RA, Mittermeier CG, da Fonseca GAB, Kent J. 2000. Biodiversity hotspots for conservation priorities. Nature 403 (6772): 853-858. DOI: 10.1038/35002501.

Nepali BR, Skartveit J, Baniya CB. 2020. Altitudinal pattern of Pteridophyte in Arghakhanchi district, West Nepal. J Pl Res 18: (1): 173-182.

Nooteboom HP. 1992. Notes on Davalliaceae I. The genera Araiostegia, Davallodes, Leucostegia, and Gymnogrammitis. Blumea 37 (2): 165187.

Nooteboom HP. 1994. Notes on Davalliaceae II. A revision of the genera Davallia. Blumea 39: 151-214.

Nooteboom HP. 1998. Flora Sumatra dan Kepulauan Mentawaina, Series 2. Ferns and Ferns Allies. Vol III. Rijksherbarium/Hortus Botanicus, Leiden, Neitherland.

Parris BS Latiff A. 1997. Towards a pteridophyte flora of Malaysia: A provisional checklist of taxa. Mal Nat J 50: 235-280.

Patil S, Lavate R, Rawat V, Dongare M. 2016. Diversity and distribution of pteridophytes from Satara District, Maharashtra (India). Plant Sci Today 3 (2): 149-156. DOI: 10.14719/pst.2016.3.2.216.

PPG I. 2016. A community-derived classification for extant lycophytes and ferns. J Syst Evol 54 (6): 563-603. DOI: 10.1111/jse.12229.

Rajbhandary S. 2016. Fern and Fern Allies of Nepal. In: Jha PK, Siwakoti M, Rajbhandary S (eds) Frontiers of Botany. Kathmandu, Central Department of Botany, Tribhuvan University, Nepal.

Rohlf FJ. 1998. NTSys-pc. Numerical Taxonomy and Multivariate System. Version 2.02. Exeter Software, New York.

Salazar L, Homeier J, Kessler M, Abrahamczyk S, Lehnert M, Krömer T, Kluge J. 2015. Diversity patterns of ferns along elevational gradients 
in Andean tropical forests. Plant Ecol Divers 8 (1): 13-24. DOI: 10.1080/17550874.2013.843036

Schuettpelz E, Rouha G, Pryer KM, Rothfels CJ, Prado J, Sundue MA Windham MD, Moran RC, Smith AR. 2018. Are there too many fern genera?. Taxon 67 (3): 473-480. DOI: 10.1270 5/673.1.

Shieh WC, DeVol CE, Yang TY. 1994. Davalliaceae. In: Huang, TC, Hsieh CF, Keng H, Shieh WC, Tsai JL, Hu JM, Shen CF, Yang KC, Yang, SY (eds) Flora of Taiwan. Tah Jinn Printing Company, Taipei.

Schneider H, He L, Hennequin S, Zhang X-C. 2013. Towards a natural classification of Pteridaceae: Inferring the relationships of enigmatic pterydoid fern species occurring in the Sino-Himalaya and Afro$\begin{array}{llll}\text { Madagascar. Phytotaxa } & \mathbf{7 7} & \text { (4): 49-60. }\end{array}$ 10.11646/phytotaxa.77.4.1.

Smith AR, Pryer KM, Schuettpelz E, Korall P, Schneider H, Wolf PG. 2006. A classification for extant ferns. Taxon 55 (3): 705-731. DOI: $10.2307 / 25065646$

Tsutsumi C, Chen CW, Larsson A, Hirayama Y, Kato M. 2016. Phylogeny and classification of Davalliaceae on the basis of chloroplast and nuclear markers. Taxon 65 (6): 1236-1248. DOI: 10.12705/656.2.

Vidyashree CSY, Hemla NB, Jadeyegowda M, Revannavar R. 2018. Diversity of fern flora for ecological perspective-a review. Int J Pure Appl Biosci 6 (5): 339-345. DOI: 10.18782/2320-7051.6750.

Wei R, Ebihara A, Zhu YM, Zhao CF, Hennequin S, Zhang XC. 2018. A total evidence phylogeny of the lady fern genera Athyrium Roth (Athyriaceae) with a new infrageneric classification. Mol Phylogenet Evol 119: 25-36. DOI: 10.1016/j.ympev.2017.10.019.

Whitten T, Damanik SJ, Anwar J, Hisyam N. 2000. The Ecology of Sumatra, The Ecology of Indonesia Series. Vol I. Periplus.

Xiang X, Hua-yong Z. 2017. Area corrected species richness patterns of vascular plants along a tropical elevational gradient. J Mt Sci 14 (4): 694-704. DOI: 10.1007/s11629-016-3894-6.

Xing FW, Wang FG, Nooteboom HP. 2013. Davalliaceae. In: Wu ZY, Raven PH, Hong DY (eds) Flora of China, (Pteridophytes). Science Press, St. Louis, Missouri Botanical Garden Press, Beijing. 